\title{
Romano-Indian Rouletted Pottery in Indonesia
}

Received August 1976

\author{
MICHAEL J. WALKER AND S. SANTOSO
}

\section{INTRODUCTION}

HE PRESENCE of Romano-Indian rouletted grey ware in northwest Java provides evidence of trade between India and Java during the first two centuries A.D.

1 The pottery comes from precisely that region of Java which c. 450 A.D. was known as Tārumā and seems to have been a recipient of Sanskritic culture.

In 1976, we conducted investigations into earthenwares of the northwest Java "Buni Complex" (Sutayasa 1972) and drew some 350 intact vessels at the Pusat Penelitian Purbakala dan Peninggalan Nasional and the Museum Pusat (Central Museum), thanks to the kind permission of R. P. Soejono at the former and of Professor Bambang and Mr. Sulaiman at the latter. A full study is in preparation for publication. Suffice it to say that the complex comprises buff, brown, or grey cooking pots, pot lids, and shallow bowls or dishes, as well as occasional flasks with tall necks. Apart from these last, the ware is coarse and ill-fired with micaceous or quartz filler and usually plain. The flasks often have incised concentric zonal decoration, and other vessels may have zonal incised chevrons, grids, and stamped decoration. One vessel bears stamped swastikas in circles, suggesting Indian influence. Often a red wash (slip?) is present on the upper part of cooking pots which have everted rims on which the color is present inside as well as out. Pedestals and foot rings are very rare, but omphalos bases are not uncommon, likewise flat bases, although convex bases are the most frequent kind. The bodies of cooking pots are globular, sometimes carinated. Rims are usual, true necks infrequent. In some cases rims seem to have been added separately before firing, whereas in others rims were made of a piece with the body.

Michael Walker is a lecturer in the prehistory section of the Anthropology Department at Sydney University. S. Santoso is on the staff of the Pusat Penelitian Purbakala dan Peninggalan Nasional (National Research Center for History and Archaelogy), Jakarta. 
Most finds come from northwest Java, and particularly from that area now under paddy watered by the rivers Bekasi, Citarum, Parage, and Cilamaya ( $c i=$ 'water,' 'river'), which have made a wide alluvial floodplain. Three groups of sites occur on it (Sutayasa 1972), one between the Bekasi and Citarum, a few $\mathrm{km}$ from their mouths (near the villages of Buni, Kedungringin, Bulaktemu, Kebon Klapa, Batujaya, and Pulo Glatik), another $18 \mathrm{~km}$ northeast of Rengasdengklok (near Kobak Kendal, Dongkal, Cibutak, Pojoklaban, Tegalkunir, Babakan Pedes, Turi, Karangjati, and Cilago), and a third at Cibango near the mouth of the Cilamaya. The pots were found during agricultural operations by local people and later were acquired by the Research Center or the Museum. One trial archaeological excavation showed only that much disturbance and mixing of material had occurred at the place chosen, an unsurprising finding because agricultural irrigation and drainage ditches have been dug continuously for probably 1500 years: An inscription of King Purnavarman of Tārumā c. 450-500 A.D. tells of such operations (Târumā is identified by historians with the Tarum River region).

\section{ROMANO-INDIAN WARE}

Hitherto, archaeology has not succeeded in establishing clear links with India, despite Sanskrit inscriptions and Indian names (e.g., Purnavarman). Much Buni Complex material shows resemblances with Bengal vessels studied by J. Birmingham of Sydney University, and ceramic relationships do not seem to lie in the direction of the Sa-huynhh/Kalanay traditions of Vietnam and the Philippines, although the latter do reach eastern Indonesia. In this article, we shall confine attention to import ware, which, notwithstanding its scarcity, alone among the Buni Complex vessels can be categorically said not to be made locally. We refer to Romano-Indian rouletted fine ware.

Figure $1 a$ shows a large piece of this from Kobak Kendal in the Research Center collection. The dish measures $300 \times 60 \mathrm{~mm}$ and is of thin $(6 \mathrm{~mm})$ brittle ware which gives a bell-like ring when tapped. The body is grey in cross-section and on its inner surface, but the outer was treated with a red wash or slip (it is uncertain which). Microscopic grains of quartz or mica (the petrology has not yet been carried out, but is in hand) might represent materials present in the clay or else finely ground filler. Surfaces are very smooth, and perhaps were polished. An absence of telltale striations indicates that a fast-wheel was used, though later treatment could have obliterated them. A circular band of rouletted dots is present on the inside, the impressions being somewhat blurred, perhaps also due to subsequent treatment. Figure $1 b$ shows another large piece at the Center from the same locality. This dish measured $290 \times 45 \mathrm{~mm}$ and is even thinner $(4.5 \mathrm{~mm})$. The ware is grey in cross-section and on the inner surface, but the outer surface is pink. There is no sign of wash or slip. Two concentric bands of rouletting are present, showing different patterns. There is also a shallow groove running around the upper part of the vessel. The third piece is an intact dish in the Museum Pusat (Fig. 1c), also with two concentric rings of decoration. It measures $275 \times 50 \times 6 \mathrm{~mm}$. No cross-section of the fabric presented itself. The inner surface is grey, but the outer is red-brown and both polished and burnished, though not treated with a wash or slip. The rim is more complicated, having an inturned beak and also milled decora- 

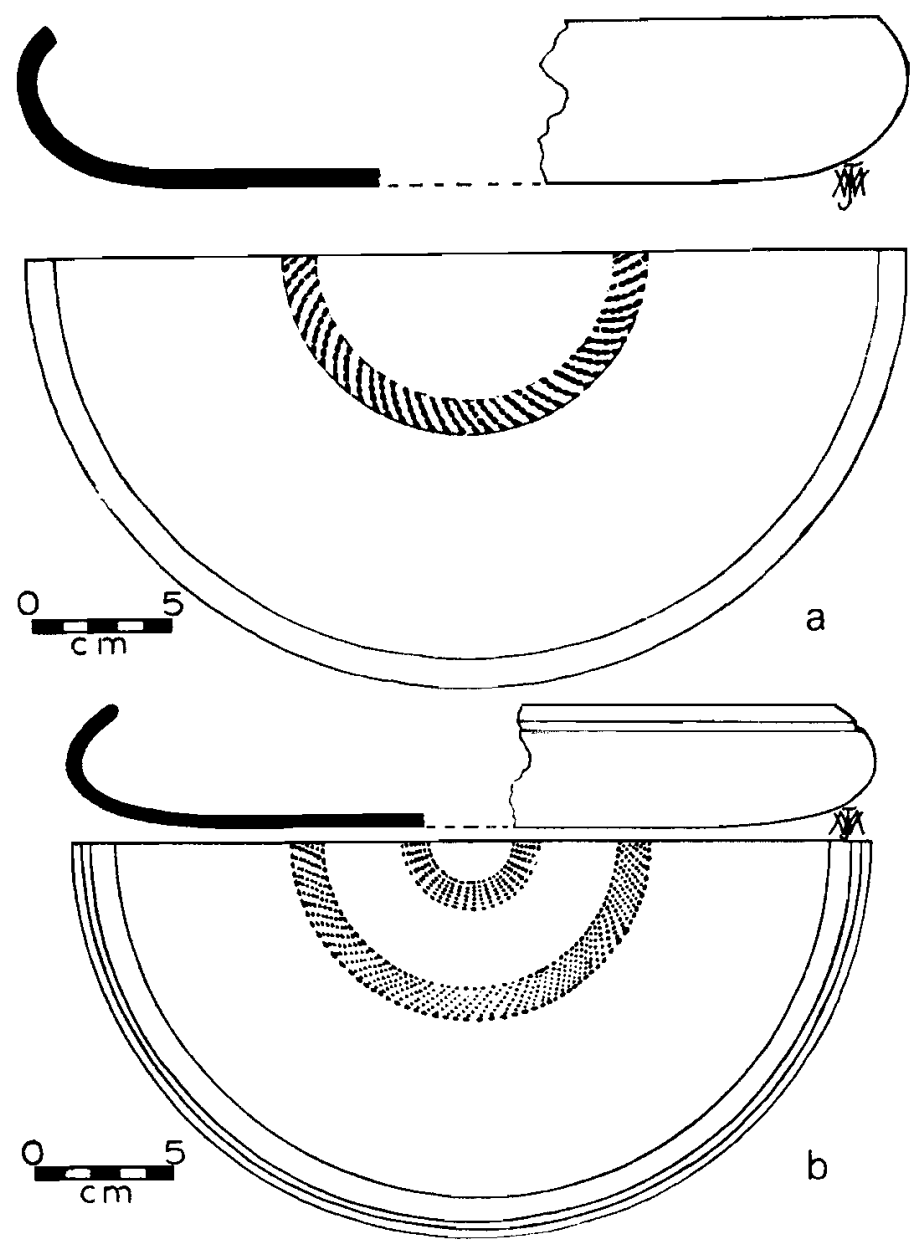

illia:

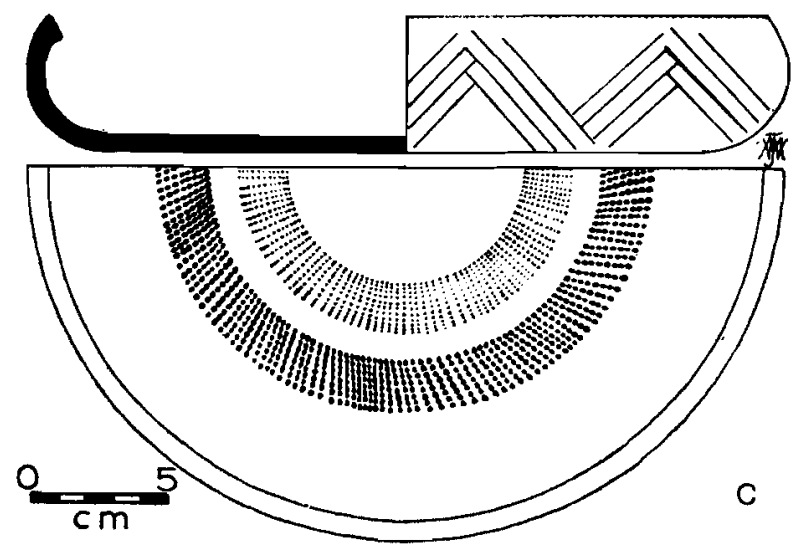

Fig. 1 Romano-Indian rouletted ware from $(a, b)$ Kobak Kendal and (c) Cibutak, Indonesia. 
tion. The outside has running incised chevron decoration. Again, the rouletting shows two different patterns. Unlike the other vessels, the rouletting is sharply impressed. The piece comes from Cibutak.

Some other dishes which lack decoration seem to be made of very similar material. In one or two cases, they have omphalos bases. These will be published along with the rest of the Buni Complex pots, since it cannot yet be stated that they are imports.

\section{Discussion}

There is no doubt whatsoever that this ware is identical to much of that published from many Indian locations, with the single exception of Figure $1 c$, where exterior decoration is shown - a feature not characteristic of the subcontinent. Krishna Deva (in Wheeler et al. 1946) described rouletted ware at Arikamedu, and his account was included along with accounts of Arretine ware and of amphorae under the general heading of wares imported from the Mediterranean, separated from the next heading "Local Wares." He wrote, however,

A characteristic pottery-type of Arikamedu is a dish (Type 1) sometimes more than 12 inches in diameter, with an incurved and beaked rim which usually has a faceted edge. The ware has a remarkably smooth surface, is thin, brittle and well-burnt, and has an almost metallic ring. The flat interior is normally decorated with two, occasionally three, concentric bands of rouletted pattern. This pattern is not an Indian feature and may be regarded as an importation from the Mediterranean region, but it has not yet been possible to ascertain whether the type itself is of similar origin. It may in any case be presumed that the varieties with distinctly inferior fabric and degenerate rouletted pattern were manufactured locally. (Wheeler et al. 1946)

The ware was often slipped, the commonest of five slip types being "greyish pink ware, grey slip inside, brown to sepia outside." The Arikamedu stratigraphy permitted further subdivisions to be made. Generally speaking, the more incurved, less vertically walled dishes were associated with Arretine import ware; likewise dishes with pronounced beaked rims. Both forms, however, occasionally seem to have continued down to the end of the second century, while high external grooving (cf. Fig. 1b) was never found before the appearance of Arretine ware (perhaps c. 20-50 A.D.), although rouletted ware did occur prior to that time at Arikamedu. Burnished rouletted dishes there came mainly from pre-Arretine layers, but burnish was more often on inner, not outer, surfaces. Sharply impressed roulette motifs were said also to be early and not post-Arretine in general. Those criteria could be used to argue an early first century date for Figure $1 c$. The running parallel chevrons of this piece might be paralleled in criss-crossing painted chevrons on russet-coated painted "Āndhra" ware, whose forms include bowls just like those of rouletted ware, occurring often at the same sites as the latter, and being contemporaneous with it (Wheeler et al. 1946: 48; Wheeler 1947-1948: 236-237, 227-278, 308-399).

At Arikamedu, rouletted ware occurs in pre-Arretine (pre-20 A.D.), Arretine, and post-Arretine levels, through to the end of the site c. 200 A.D. Casal (1949) compared 
it with Etrusco-Campanian rouletted decoration, but there the similarity ends. Rouletted ware is known from other South Indian sites, namely Amarāvatī (Wheeler et al. 1946), Brahmagiri and Chandravalli (Wheeler et al. 1946, Wheeler 19471948), Kondāpur and Maskī (Wheeler 1947-1948), Uraiyur (Indian Archaeology 1964-65: 256; hereafter, $I A$ ), and Maigramam (IA 1961-62: 26-27). From north India it is known at Tamluk ( $I A$ 1954-55: 19-20), Chandraketugarh (IA 1956-57: 29-30; 1957-58: 51-52, 70; 1959-60: 50-52), Rajghat (IA 1963-64: 59-60), Siśupālgarh (Lal 1949: 86-87), and Baral (IA 1957-1958: 51-52, 70). Can we date rouletted ware at these sites? Are there chronological divergences from Arikamedu? The short answer is no. But it is hard to be precise. Tiberian currency found at Chandravalli was at first thought to come from layers which contained rouletted ware (Wheeler et al. 1946), but subsequently it was said that the money could have been dropped as late as the second century (Wheeler 1947-48). Later excavations at Maski (Thapar 1957: 72-76) did not find any more rouletted ware, but russetcoated painted ware was encountered. At Siśupālgarh, rouletted pottery occurred in levels earlier than one in which there was a find of the second century Kushāna monarch Huvishka, the site continuing down to c. 350 A.D. Despite the occurrence of rouletted ware at Tamluk, it is conspicuous by its absence at Patna (cf. Altekar and Mishra 1959). At Chandraketugarh, the first two periods do not have rouletted ware, and it appears either contemporaneously with $(I A$ 1956-57) or somewhat after ( $I A$ 1959-60) the appearance of northern black polished ware, continuing during Sunga-Kushan times, and even into those of early Gupta ( $I A$ 1957-58). However, the Gupta phase is characterized, as at other sites, by stamped ceramic ornament, not by rouletted ware. Plain flat base dishes of northern black polished ware have profiles like those of rouletted ware, and one (IA 1956-57:29, fig. 14) has an internal central circular motif from which triangles radiate like the points of a compass, perhaps foreshadowing circular ornament of later rouletted ware, notwithstanding the Mediterranean inspiration of the latter. At Rajghat, the single sherd of rouletted ware occurred in Layer 4 (IA 1960-61), but it is not stated whether this corresponded to pre-Gupta, Gupta, or later levels of occupation.

There is a widespread occurrence in India of grey-pink fine ware dishes lacking decoration, but otherwise like rouletted dishes. The authors have found these too on Java. But, as has been mentioned, the profiles have considerable antiquity in India, and it would be unwise to attribute these to foreign craftsmen. It seems likely that rouletted dishes were made in India rather than farther west. Whether they were made by Mediterranean or local craftsmen we cannot tell. It does not much matter, since if the latter were the case, they would have most likely been instructed by foreign potters, perhaps the same ones who copied Arretine ware at Arikamedu. That rouletted ware continued until the late second century suggests the type was adopted by Indian craftsmen as their own.

Distribution of rouletted pottery in India suggests dispersal from a center in southern India in close contact with inland towns, and trading up the coast as far as the Ganges delta. Classical sources refer to coastal trade known to the Romans and Greeks as far as the Bay of Bengal (Warmington 1974), though they themselves seem rarely to have penetrated far north. Arikamedu was probably one of their emporia, perhaps Ptolemy's Podoukē (Casal 1949). Since knowledge of the southwestern monsoon was brought to the attention of classical writers by "Hippalos," 
there was theoretically no obstacle to trade across the Bay of Bengal. Classical writers, however, are vague about the geography of its eastern littoral, despite mentions by Pomponius Mela, Pliny, Ptolemy, and others. Indian sources are unhelpful about trade with Southeast Asia, while it is unlikely the Chinese even had coastal trade as far south as Malaya in the first century A.D. and do not seem to have been capable of building and navigating oceangoing craft for use in the South China Sea, let alone farther west, until at least the fourth century (Wheatley 1961; Wolters 1967). Indonesian-Malayan sailors were very competent, however. Some scholars have even suggested they spread Austronesian languages to Malagasy on the far side of the Indian Ocean before the birth of Christ; at any rate, it was not long after that date. Of course, maritime trade was not necessarily direct. It could have been coastal or even overland. In support of the last-mentioned are perhaps the kettledrums of bronze from Indonesia which were probably inspired by southwest Chinese examples. They could have been made locally, however, and a stone mold for the making of these is known from Bali (though it might be late). Van Heekeren (1958) has drawn attention to motifs on a drum from Sangeang Island, including houses on piles with saddle-shaped roofs (cf. modern houses from Sumatra, Sulawesi, and other locations), and human figures sporting clothes both of Han China and Kushāna India, which argue for perhaps an early second century A.D. date.

This article is not the place to discuss such esoteric possibilities as whether King Tiao-pien of Ye-tiao, known to the Chinese c. 130 A.D., was or was not a rendering of a putative King Devavarman of Yāvadvipa; that is to say, a king bearing an Indian name of an Indonesian island known to Indians and Chinese by an Indiantype name. Many scholars firmly assert that even the presence in Indonesia of Amarāvatī Buddha statuettes does not signify that Indianization was very marked. Certainly, Chinese accounts of Indochina from the third century testify to burial practices far removed from those of traditional Hinduism. Nor is this article the place for a full description of coarse pottery with Indian similarities from northwest Java, though such pottery does exist. Suffice it to say in that connection that pot lids of upturned mushroom shape are the main Javanese type (we have only seen one convex pot lid) corresponding especially to Wheeler's types $36 \mathrm{a}$ (and, less often, $39 \mathrm{a}$ or 40c) at Arikamedu. Type 36 was said to be "very rare" and was only known from pre-Arretine and Arretine layers at Arikamedu, while types 39 and 40 were from post-Arretine layers (Wheeler et al. 1946). So-called "incised" ware (Wheeler et al. 1946: p1. XXXI C2) is in fact the very common mat/basket/raffia-impressed motif, caused by the type of fabric wrapped around the potter's paddle, which we have encountered in northwest Javanese "Buni Complex" pottery (also cf. Wheeler et al. 1946: pl. XXXII B2). It was not common at Arikamedu but is found in some parts of eastern India. Stamp-impressed and red wash/slip pottery of the postArretine layers at Arikamedu, and well-known from India in the second, third, fourth, fifth and possibly later centuries, is also well represented in northwest Java.

Tārumā was known to the Chinese in the seventh century as To-lo-ma, but scholars have pointed out that the name is paralleled in southern India at a place some $20 \mathrm{~km}$ north of Cape Comorin (Coedès 1968:54). Wolters was surprised that as early as the sixth and seventh centuries his historical investigations demonstrated considerable trade emanating from Java, especially with China (for which records 
are better than for India). The archaeological evidence suggests that such trade goes back to the first century A.D. True, Indianization of Indonesia may have been a drawn-out affair over many centuries, depending on the awareness of Indonesian princes of advantages to be gained from adopting Indian culture and religions in terms of their own local politics. Yet the finding of pottery in paddy fields, especially cooking pots with lids, feeding bowls, and serving dishes, suggests the common people too may have acquired Indian-inspired material objects. Unlike Sumatra, Java is agriculturally rich, though the dominant crop has been always rice. Not only burials but also food offerings to animistic spirits guarding the paddy fields might have been associated with the pottery-this is a guess at random. But Java is farther from the mainland than Sumatra, and therefore was terra incognita to Chinese travelers for many centuries. It is not surprising we know so little about it from written sources. Historians have played down the importance of navigation in the Straits of Malacca and the Sunda Straits in early times because of lack of documentary evidence. Perhaps the future will reveal archaeological evidence of maritime connections which documents have not provided. At present, we know little about southern Sumatra and western Java in the first two centuries A.D., but evidence of statuary, especially from Sumatra, suggests a society with domesticated elephants, buffalo, and horses. Various aspects of the material culture are depicted, too, such as kettledrums, bangles, beads, swords, helmets, and even a rice mortar. Bronze kettledrums show horses, also. One grave assemblage in Java provided remains of a goat. Bronze (mainly a copper-lead alloy) and very occasionally gold were known, as well as iron. Almost certainly, horses were acquired from India, and perhaps were the most highly prized commodities of all that the subcontinent had to offer. Trade with Funan in the lower Mekong region may have been partly responsible for arrival of Roman material (coins and medals of second-century emperors, a bronze lamp, a figure of Poseidon), though alternative routes involving portage over the Kra isthmus or even routes wholly overland from the Ganges delta might be envisaged. Hitherto, sea routes from the south to Funan have been dismissed by historians, but the discovery of Romano-Indian ware demands a reconsideration of these. At later times, Śrivijaya was a staging post where goods from India were transferred for export to China (Wolters 1967). Perhaps Island Indonesia already played this role in the first and second centuries A.D. Our discovery of rouletted ware means at the very least that such a possibility must be added to other possible routes of east-west trade.

\section{REFERENCES}

Altekar, A. S., and V. Mishra

1959 Report on Kumrahar Excavations 1951-1955. Patna: K. P. Jayaswal Research Institute.

CASAL, J. M.

1949 Fouilles de Virampatnam-Arikamedu. Paris: Commission des Fouilles Archéologiques.

CoEdÈs, G.

1968 The Indianized States of Southeast Asia. Canberra: Australian National University Press. 
HeEkeren, H. R. vaN

1958 The Bronze-Iron Age of Indonesia. The Hague: Martinus Nijhoff.

Indian Archaeology 1954-55-A Review

1955 New Delhi: Government of India.

Indian Archaeology 1956-57-A Review

1957 New Delhi: Government of India.

Indian Archaeology 1957-58-A Review

1958 New Delhi: Government of India.

Indian Archaeology 1959-60-A Review

1960 New Delhi: Government of India.

Indian Archaeology 1961-62-A Review

1964 New Delhi: Government of India.

Indian Archaeology 1963-64-A Review

1967 New Delhi: Government of India.

Indian Archáeology 1964-65-A Review

1969 New Delhi: Government of India.

LAL, B.

1949 Siśupalgārh 1948: An early historical fort in eastern India. Ancient India 5: 62-105.

Sutayasa, M. D.

1972 Notes on the Buni pottery complex. Mankind 8: 182-184.

ThaPAR, B. K.

1957 Maski 1954: A chalcolith c site of the southern Deccan. Ancient India 13: 4-142.

WaRMington, E. H.

1974 The Commerce between the Roman Empire and India. 2nd ed. London: Curzon Press.

WHEELER, R. E. M.

1948 Brahmagiri and Chandravalli 1947: Megalithic and other cultures in the Chitaldrug District, Mysore. Ancient India 4: 181-310.

Wheeler, R. E. M., A. Ghosh, and Krishna Deva

1946 Arikamedu: An Indo-Roman trading station on the east coast of India. Ancient India 2: 17-24.

Wheatley, $\mathrm{P}$.

1961 The Golden Khersonese : Studies in the Historical Geography of the Malay Peninsula before A.D. 1500. Kuala Lumpur: University of Malaya Press.

WOLTERS, O. W.

1967 Early Indonesian Commerce : A Study of the Origins of Srivijaya. Ithaca, N.Y.: Cornell University Press. 